Dossıê RADIO WITH IMAGES:

\author{
an attempt to systematize the use of \\ videos on radio webpages
}

Copyright (C) 2012

SBPjor / Brazilian

Association

of Journalism

Researchers

DÉBORA CRISTINA LOPEZ

Universidade Federal de Santa Maria (RS)

\begin{abstract}
This article presents some results of the study "Periodismo radiofónico y convergencia: un estudio comparativo sobre la influencia de las tecnologías de la información y de la comunicación en emisoras brasileñas y españolas". We start with the discussions on hypermedia radio followed by an analysis of the use of video on websites of the Brazilian radio stations Gaúcha and Guaiba and the Spanish stations Cadena SER and RTVE. Using content analysis methodology, we propose a classification of videos into institutional and journalistic categories that are each subdivided into: a) exclusive, b) supplemental (either meta-journalistic or journalistic) and c) overlay. We emphasize that the rating of the journalistic content was based on the Spanish stations' production, since the Brazilian broadcasters did not use this content during the analyzed period.
\end{abstract}

Keywords: Radio and convergence; video; journalism formats

\title{
RÁDIO COM IMAGENS: uma proposta de sistematização do uso de vídeos em páginas de emissoras de rádio
}

RESUMO - Este artigo apresenta alguns resultados da pesquisa "Periodismo radiofónico y convergencia: un estudio comparativo sobre la influencia de las tecnologías de la información y de la comunicación en emisoras brasileñas y españolas". Nele, partimos dos debates sobre rádio hipermidiático e trabalhamos fundamentalmente o uso de vídeos em sites das rádios brasileiras Gaúcha e Guaíba e das espanholas Cadena SER e RTVE. Por meio da metodologia da Análise de Conteúdo, propomos uma classificação dos vídeos para rádio em institucionais e jornalísticos, sendo estes subdivididos em: a) exclusivo; b) como complementação (que por sua vez pode ser metajornalística ou jornalística); e c) como sobreposição. Ressaltamos que a classificação do conteúdo jornalístico foi construída a partir da produção espanhola, já que as emissoras brasileiras não utilizaram esse conteúdo durante o período em que foi realizada a coleta.

Palavras-chave: Rádio e convergência; video; formatos jornalísticos.

\section{RADIO CON IMÁGENES: \\ Una propuesta de sistematización del uso de vídeos en las páginas webs de emisoras de radio}

RESUMEN - Este artículo presenta algunos resultados de la investigación "Periodismo radiofónico y convergencia: un estudio comparativo sobre la influencia de las tecnologías de la información y de la comunicación en emisoras brasileñas y españolas". En ella, partimos de las discusiones sobre radio hipermediática y analizamos el uso de vídeos en las páginas webs de las emisoras brasileñas Gaúcha y Guaíba y de las españolas Cadena SER y RTVE. A través de la metodología de análisis de contenido, proponemos una clasificación de los vídeos para radio en institucionales y periodísticos, . Estos, a su vez, se subdividen en: exclusivos, de complementación (que pueden ser metaperiodísticos o periodísticos) y de superposición. Destacamos que la clasificación del contenido periodístico ha sido construida a partir de la producción española, dado que las emisoras de Brasil no han utilizado ese contenido en el periodo de análisis.

Palabras clave: radio y convergencia; vídeo; formatos periodísticos. 


\section{Introduction}

This article presents the partial results of the project "Periodismo radiofónico y convergencia: un estudio comparativo sobre la influencia de las tecnologías de la información y de la comunicación en emisoras brasileñas y españolas"2. In this study, which analyses radio stations in both countries, we intend to observe how the process of convergence and the advent of technology in newsrooms have affected the journalistic routines in this medium.

We present an outline of the project approach, examining the uses of video sites by four radio stations: the Brazilian informative channels (MEDITSCH, 2001) Gaúcha and Guaíba and the Spanish generalists (MARTINEZ-COSTA; DÍEZ UNZUETA, 2005) Radio Nacional and Cadena SER. The proposal is to observe how they explore the potential of video in their institutional communication, in their journalistic production and as a strategy of rapprochement with the listener. Our main objective is to understand the role played by videos in their pages and, consequently, to discuss their role in contemporary radio and radio journalism.

To that end, we combined two methodological tools: content analysis - CA (HERSCOVITZ, 2007) and structured interview. The interviews with professionals from the stations were designed to clarify how productive routines work in stations and dispel the doubts that arose during the content analysis. The interviews were conducted in early 2011 and included journalists who work and / or participated in the process of envisioning the insertion of the broadcast stations into the contexts of convergence and digital communication.

To develop the content analysis of the broadcasting station pages we first made use of a methodological tool developed by researchers Avelino Amoedo, Elsa Moreno Moreno and María del Pilar Martínez-Costa in the project "Evolución de los cibermedios españoles en el marco de la convergencia. Multiplataforma e integración periodística" ${ }^{3}$. This tool was adapted by the author to serve the purposes of this study and resulted in a table of analysis that seeks to contemplate ways of transmission and presentation of videos, structure and format, editorial guidelines and the basic roles they take on in the website. With most of the variables we tried to work with quantifiable elements but we are aware that some of the elements have been derived from observations and analyzes from the interviews and CA.

Content analysis was initiated with a pre-analysis (BARDIN, 2002) that allowed us to approach the subject and also to carry out an initial 
classification between corporate videos and broadcast journalism in the analyzed pages ${ }^{4}$. In the central stage of CA we analyzed the main page of the station website, specifically with regard to journalistic videos, for five days - between 07 and 11 February 2011. The broadcasting stations' pages were observed once daily, navigating the contents and collecting images for later analytical review. At the end of the analysis, we intend to propose a classification scheme for radio website videos.

The initial research hypotheses were: a) There is a distinct pattern of video use in Spanish and Brazilian radio web pages, the former being more focused on the production of news content and the latter more focused on video as a strategy of rapprochement between listener and broadcaster; b) The video plays a key role in hyper-mediatic radio, but it must work with a different profile that takes into account the intended audience, the goals of the page in which it operates and its fruition context.

\section{Radio in a digital environment}

The advance of information and communication technology in journalism - both in the newsroom routines, product design and its mode of transmission or consumption - initially exerted a more direct influence on the printed media. As Luciana Mielniczuk (2003) reminds us, the newspapers were the first to use the Internet as a new medium for transmitting information. However, it can be seen that over the years other media have joined in using both online and digital technologies of production and transmission.

Radio, which is a technological medium by nature (LOPEZ, 2009), found some of its key drivers of change in mobile phones and the Internet (DEL BIANCO, 2004; RIBEIRO e MEDITSCH, 2006). As Spanish researcher Angel Faus Belau (2001) points out, the medium is now facing the most intense challenge of its history, demanding changes, adaptations and reinterpretations of its setting, its objectives and the way it handles news. The changes, as it turns out, are not highly technological. They are, as in most convergence cases, driven by technology, but not restricted or determined solely by it (SALAVERRÍA; NEGREDO, 2008).

It is, in fact, a much wider process, involving many actors and scenarios. The radio, which has always made use of audio narrative to speak to its audience, now addresses it in multimedia. Radio has diversified and expanded its channels of interactivity (LOPEZ, 2010) and now accompanies the listener at times that were formerly not possible 
- through texts, photographs, info-graphs. The radio now speaks to a public that is already inserted in the context of convergence culture (JENKINS, 2006); one that includes 6u/

multiplatform media consumption, and speaks to information consumers who use digital tools - whether in ATM, on the smartphone, browsing the Digital TV guide, in the instrumental use of computers or other daily activities.

The increase in information sources through newspapers, magazines, radio and TV, journalism sites, social networks and mobile applications is identified among the authors of radio and radio journalism as one of the reasons for the aging of the audience in the medium. According to data provided by the stations studied in this project, the average age of the radio-listening public is over 40 to 50 years old. But according to the deputy director of interactive media of Radio y Televisión Española, Ignacio Gómez Hernández (2011), the advent of the internet in the radio stations, the exploitation of the potential of the network and marking presence in social networks can help to rejuvenate the audience.

It is important to remember that typically the radio listener is interactive. Whether through letters, phone calls, text messages, visits to the station, email, chats, forums or social networks, the public is always present in programming - and nowadays is present on the stations' sites as well. This participation can take place both synchronously and asynchronously (LOPEZ, 2010) and not only creates contents but also demands different responses from the communicator. These spaces also interact with the rest of the content and possibilities of the page such as validation and circulation of journalistic content. Part of the process of bringing the listener is connected to the circulation of the broadcaster and its professionals in spaces that shared in common - for example, social networks. The ability to share a video - either indicating by Facebook or by providing embed code on Orkut - leads the station to the audience's space, allowing it to reach users who do not usually compose their everyday audience.

Thus radio, in a converged environment, immersed in the context of information and communication technology, maintains its narrative strategies and makes use of tools that enable it to approach and make contact with its listeners - now listener-internet users. This medium, that has now become hyper-mediatic (LOPEZ 2010), builds a multimedia narrative in which there is an ongoing dialogue involving static and moving images, info-graphs, written text and audio - and this last is their main focus, constituting the backbone of the information supply to its users. It 
also takes pains to keep close to its listeners by circulating in their spaces of dialogue, listening to them (as it always has done, but nowadays it does so through new and multiple channels), increasingly allowing the audience to help directly or indirectly in constructing information and the profile of the broadcasting station itself.

Besides the requirement of increased participation, the presence of the radio medium in a multimedia support demands its adaptation and the adoption and creation of new formats and new languages that explore the potential of the internet and allow the listener-internet user to do so too (LOPEZ , 2010). However, as the former director of contents of the Spanish radio Cadena SER, José María García Lastra (2011), reminds us, it is essential that companies and communicators, when inserted in this context, keep in mind a clear distinction between the profile of each individual medium and the characteristics of a multichannel, or multiplatform production. Thus, in support of the concept of hypermediatic radio, García Lastra says the radio needs to think about its brand, its identity as a medium. To that end, its production - whether as news, sport or entertainment - should keep its focus in the web on audio and display other elements of multimedia language as a support for sound.

Thus multimedia language plays an important role in hypermediatic radio, in supporting audio, complementing and expanding the information and exploration of the potential of the platform. Its various formats have, in this new radio configuration, different functions, ranging from public utility boosted by a graph or info-graph, to image galleries and videos of station events or introducing the broadcasting station to new audiences.

The video, in particular, serves for several of these potential uses and maintains itself as a production with contents sourced from the radio medium offering new formats and visual language strategies whose aesthetics are quite distinct from TV news broadcasting, as we shall see below.

\section{Visual language}

Television is image. It is responsible for bringing the viewer information - combined with text, sound environment, and speech. But the image is a protagonist. "[...] the first step in writing a text for TV is to find out what images that may be used in editing. One needs to know what will be use in order to harmonize the words with the images 
"(BARBER; LIMA, 2002, p. 97). The story is told in televisual journalism through a polished and rhythmic editing of images, accompanied by a normally non descriptive narrative in off (PATERNOSTRO, 2006) and that takes up journalists' time and work of journalists as they strive for high technical quality in their editing.

Information on television, the author reminds us, is eminently visual. It is characteristic of the medium that it requires focused attention of the public, and largely, exclusivity in action and consumption of content. However, as stated earlier, the image does not stand alone. According to Ruge (1983), three components are crucial in defining the effect of an audiovisual transmission: informational perspective of an image, the image's potential for stimulating the senses and their acoustic components, like the word, music or sound effects. These components are able to create and switch scenarios in delivering the message. "These scenario changes arouse the interest, indicate that something new is beginning. The viewer enters back into the action thanks to the variety of images. The changes of scenario can be the formal arousers of narrative tension" (RUGE, 1983, p. 40).

Thus, the creation of journalistic television products involves a complex process, capable of composing a compelling and believable speech. As noted by Maria Jose Castillo (2004, p. 25) "Audiovisual language splits reality into credible times and spaces. The camera captures real images to construct a narrative that is believable (reporting, documentary, etc..)". In this re-composition of a fragmented reality, rhythm and treatment of narrative time in a television product play a crucial role. The author (2004, p. 313) further explains that the assembly of audiovisual content is not just a collage of plans, but a creative process that requires rhythm and strength. The medium of communication that by its very nature requires the audience's attention almost exclusively needs to keep its attention and avoid the zapping effect (MACHADO, 2000), establishing a pace that is a compelling and that allows for the absorption of information in journalistic productions.

In television news, says Curado (2002), the word has an important role; it is there to reinforce the meaning of the image, taking on the role of an amalgam that unites form and content. In the various genres of television products there are ahardly any that do not have as one of their important elements. Notes (succinct or elaborate), reports, interviews with audio in off - all rely on the power of the word. This is a strategy to ensure the transmission of the message to a wider audience of viewers - especially when it comes to hard news journalism. 
The audio, however, is not composed of words alone - and television production carefully observes this marriage between elements of audio language as a strategy to engage the audience and give a narrative sequence to the text. "Somehow, the sound is the "glue" that binds successive image planes of an assembly, the different viewpoints that it offers to the viewer" (CASTILLO, 200, p. 391). It is what Paternostro (2006) presents as the correlation between information and emotion, as the full exploitation of the medium's characteristics.

\section{Videos for radio: an attempt to systematize}

The analysis of the websites of the four radio stations reveals characteristic editorial patterns in Spanish and Brazilian stations and they compose the corpus of analysis. While the former invest more in interactivity tools on site, with the Spanish stations presenting several multimedia language productions - including audiovisual, the latter, radios Gaúcha and Guaíba, did not make use of any journalistic videos on the days that were analyzed. The transmission of news on the website of the Brazilian radio stations occurred predominantly by means of audio files made available on the page - in the nature of a memory registration - and supplemented by texts and, in some cases, photographs. That pattern differs considerably from the one observed on the RTVE and Cadena SER sites. The main purpose of the Brazilian websites, according to interviews with those responsible for defining their content, is to make available audio material that has previously been broadcast over the air ${ }^{5}$.

In this paper we analyze the uses of video in the pages of selected radio stations - the Brazilian Gaúcha and Guaíba radios and the Spanish RTVE and Cadena SER. The targets of investigation and analysis were structure, timing of production, proposed and possible interactivity, integration to other formats and the relevance of using images on radio stations. We observed a more intensive day-to-day use of video in the Spanish radios - although it is worth noting that RTVE, being a site integrated between radio and TV stations displays no videos produced specifically for the radio, but rather those designed for television and/or the group's website.

In a general approach we propose classifying the videos into the categories of institutional products and journalistic products - the former consisting of videos presenting the station and programs to the audience, "bringing" the listener close to the radio, without, however, offering any 
journalistic content as such. They can be videos shot from the wings of regular programs that show the announcers and cameras now so common in the studios. The second category includes all the journalistic productions whether they are original broadcasts or complementary to the contents broadcast via antenna.

The focus of this analysis, in keeping with the project entitled "'Periodismo radiofónico y convergencia: un estudio comparativo sobre la influencia de las tecnologías de la información y de la comunicación en emisoras brasileñas y españolas "[ Radiophonic journalism: a comparative study of the influence of ICT in Brazilian and Spanish broadcasting organizations] is journalism, hence our choice of the latter category as the object of analysis. The analysis of the videos analyzed from the websites of the radio stations identified three possible uses for them, namely: a) exclusively for the radio site b) supplementary (subdivided into meta-journalistic or journalistic) and c) as an overlay. The first use of the video is presented as a differential on the site often taking the central role of production. This is unique content, such as the program "Estudio B," of Radio Gaúcha, a video produced in the radio studio exclusively for the internet. Although it does not dialogue with the other productions of the site, the program has a strong point in the image as it presents personalities from the world of Rio Grande do Sul football history - most of whom the audience can identify more readily by their images than by their voices. In this case the consumption of the program is not complicated by other developments on the site or other platforms of the same broadcasting group because it appears only on as an online video, requiring the participation of the listener-Internet user who needs to go to the page to consume this weekly content offer.

The second use, as a complementation, can be sub-divided into meta-journalism and journalism. In both cases, the common thread is the audio production, as is to be expected for hyper-mediatic radio, but the video plays a key role in deepening and / or locating and expanding the news. The meta-journalistic complementation appears when the information production process is detailed in video - in the case of images of the journalist seeking a source who declined to correspond, or images that underscore the amount of attempts by staff to obtain the information or a simple backstage video. Journalistic complementation directly concerns information. It can be a video produced by the radio team itself or linked by the journalist for complementing audio content, but produced by other media or by the audience. An example of this category is those videos that record an event or the full version in video of 
an interview broadcast in part in audio via the station antenna. They can also be videos of citizen journalism and / or available in video delivery networks and that allows for linking and integration with embed codes like YouTube or Vimeo. The strong point of such productions is the possibility they open up of integrating to social networks and content validation systems, contributing to the enhancement of material and broadcaster visibility.

Another possibility is the use of video as an overlay, as happens, for example with the presentation of videos that deliver the same content available on the air and / or repeating information displayed in text on the station's page. The central feature of this category is that neither image nor audio content in this video are crucial to the understanding and /or complementation of the news, but repeat content transmitted to the listener-Internet user by other languages. That category meets what Salaverría and Negredo (2008, p. 58) call shovelware. "Shovelware is publishing information in bulk, without selection or adaptation to the support being used". Thus, it fails to exploit full multiplatform potential and ultimately minimizes the listeners' interest in the information.

In terms of structure of the videos, in this article we propose three distinct categories: a) implementation of the TV model, b) as a register and c) as a hybrid. The first structure has journalistic television production features, such as news with the reporter image and audio in off, highlighting the value and weight of the reporter's image on the audio or text. As we said, television is image. It is responsible for delivering information to the viewer, combined with text, sound environment, speech; the image, however is the main protagonist. As Barbeiro and Lima (2002) put it, image and words cannot be disconnected; they should compose a cohesive object and be mutually complementary. Thus, the story is told in television journalism according to a structure and building process that requires an elaborate editing technique and cannot be accomplished without the devotion of a considerable time on the part of a skilled professional. In this category therefore we include videos of the TV channels groups analyzed that were not specially adapted or videos produced exclusively for the website, but built keeping the structure of television journalism. That category is commonly found on broadcast stations websites. We believe, however, that this is largely a reflex of the professional culture that determines that videos should follow the structure of traditional television. Nowadays, however, that clashes with the convergence culture (Jenkins, 2006) and the process of mediamorphosis in course (FIDLER, 1997) indicating the need to revise formats, 
rethink content and the uses of devices, allowing platforms to engage in dialogue and manage new experiences of production and consumption of information, regardless of the medium from which they originated.

The second category, register/record, is a kind of short, unedited production that typically aims merely to register the occurrence of an event for the listener-Internet user. In this category there is greater freedom to explore the creative potential of the reporter and engage differentiated narrative strategies. For example, the use of productions without inserting offs or interviews, which set their narrative axis on the relationship between tracks, effects and images - something hardly ever done in television newscasting and, when it is, usually associated to sports clips at the closure of the newscast edition. In this case, the sense of information was given by the informational context located on website through tagging, subtitles supporting texts and audio accompanying the video. The presentation of this situating information has the function of rebuilding the fundamental context in the light of the prevailing convergence scenario. As explained by Marcos Palacios (2012), the information available online is permanent but the memory constructed in this scenario is defective, full of gaps and the consequences are usually disassociated so that only a partial view of a given subject or event is presented, distorting any eventual understanding. Thus, the construction of this context allows us to understand the argumentative strategies proposed by journalists in a particular historical moment.

Furthermore, in regard to the proposed categories we present, we must emphasize that although the usual standard for the register video is short, it can be longer. An example is the RTVE hot site on the demonstrations in Egypt in 2011. In early March 2011, after the fall of former president Hosni Mubarak, RTVE kept a camera live from Tahrir Square, where people were celebrating. The image - the same used by the broadcasting group - had only ambient sounds, exploring the potentials of the soundscape radio feature and register image as supplementary information. One downside of this transmission is specifically the fragility of memory. As the images were broadcast live and unedited, they were not available for later reference by the audience, not even partially.. The only moment of consumption possible for that particular product was during the live broadcasts ${ }^{6}$.

The third radio video structure category, "hybrid" videos, while admittedly containing a lot of elements associated to teleivision productions is also mixed with elements more typical of register videos. That means that unedited excerpts that are designed to enable the 
listener-Internet user to locate himself on the overall stage of events are linked to edited interviews with or without an image of the respective reporter thereby building a characteristic format derived from what Fidler (1997) considers to be media-metamorphosis. This last category together with the register category is what predominates on the website of Cadena SER. A typical example ids the video gallery "Where would you be if the 23-F had triumphed?" which was a collection of short interviews with artists and politicians produced especially for the website. Other examples would be soccer videos showing highlights of the match and/ or goals. In this category we were able to detect an initiative on the part of the communicators building a narrative strategy that typifies videos produced fro radio sites. It is an attempt to create productions that fit the new profile of the audience and that conduct an online search additional content to complement that consumed via the antenna broadcasting.

\section{Final Thoughts}

The initial hypotheses of this study were confirmed at the end of the analysis of the websites of the four radio stations that make up its corpus. We believe, after watching the production of radios Gaúcha, Guaíba , RTVE and Cadena SER, that there is a distinct profile of use of videos between them. The Brazilians have essentially corporate videos with the presentation of the newsroom backstage and the studio through live camera and edited productions. We can say that this is a strategy of rapprochement with the audience, bringing to the digital universe the traditional visits to the stations to meet communicators personally and to understand the process of making the radio program.

What was not observed in their pages was the constant adoption of videos in the routines of journalism, either independently or as a complement to audio and / or antenna broadcasts. One exception is the said program "Estudio B," on Radio Gaúcha. However, we believe that the existence of a program cannot be considered as crucial factor in the company's editorial policy regarding adoption of this format. As has already been stated, we see, in the action of prioritizing institutional content, a strategy for approaching the audience, showing them the image of communicators and the spaces in which content is produced. This is a common practice website with national outreach, stresses that the camera live in the studio is among the most accessed contents of the page (LOPEZ, 2010). In the stations analyzed in this project, three offer this service to the listener-Internet user - both Brazilian stations and 


\section{Cadena SER.}

The main option of the Spanish stations has been videos applied to journalism. Outstandingly, the Cadena SER develops specific content for the radio website taking into directed at the listeners thqa also have an internet user profile with a view to keeping up a dialogue between them and the stations programming. Thus, we believe that this station can be identified more clearly with the development of videos designed specifically for hyper-mediatic radio. It is important to emphasize that on the page of RTVE, as highlighted by its coordinator and as revealed by the analysis, the video plays a supplementary role, complementing the sound programs but it is also designed to appeal to the group's wider audience embracing both listeners and television viewers.

We did not observe in the analyzed period, the use of metajournalistic videos - either as complements to the live broadcast contents or as independent productions for the website. This was true for all the four stations. We believe that this absence is due to a lack of an informative quality associated to this category making it unattractive for daily news journalism. The meta-journalistic video exercises a role of verifying the actions of journalists in special productions and / or to address complaints and show that other sources of information had been sought out but declined to comment.

The journalistic content developed on video primarily operates as supplementary information. RTVE and Cadena SER predominantly offer videos that complement the content broadcast via antenna and multimedia contents on the site. Although the dialogue between platforms is not intense, the potential of the Internet is explored with integration to social networks and the possibility of sharing. The videos extend the information and enable listener-Internet users to obtain a visualization of scenarios of news events and their respective contexts. Furthermore they are mainly used when the image is what informs and avoid giving priority to overlay.

Regarding the structure, the profiles of the two Spanish radios are quite distinct. RTVE, as it is part of a group that includes TV stations and shares the same website with them, mainly works with the transposition of TV-orientated. Most of its videos have reporter participation, character generators, effects in off, standard images and timeframes typical of television news production and other TV-related features. Many of the videos are retrieved directly from TV programming them are recovered from television programming, including TV newsdesk-style presentation. It is noteworthy, however, that RTVE was the station that took the initiative 
of producing register videos, as mentioned earlier in this article. Although they do not yet prevail, nevertheless it is possible to identify innovative initiatives and specific production for the radio station webpage.

On the other hand Cadena SER actively seeks innovation. On its page you can identify a balance between the categories register and hybrid in an endeavor to build a new format from the fusion of the previous ones. Especially in the sports editorship, the station uses video as a tool to reach the listener-Internet user, offering him or her a new information consumer experience, complementary to sports broadcasting, discussion programs or the news coverage sector.

We believe from these results that in the Spanish radio stations analyzed the video plays a key role. However, as they are designed for radio and for its specific audiences and the demands it presents, they are forms of production consumed on demand and therefore depend on the initiative of the audience and its interest in their content. Furthermore, in their structuring they take into account aspects like connectivity capacity, access speed, multitasking profiles, interest in sharing and the possibility of browsing simultaneously on several pages. All this is coordinated with audio production characteristics of a radio website. Thus, the station manages to keep the listener-Internet user interested and involved with the information presented, exploring the potentials and differentials of the video in a medium that is eminently auditory.

We also note that the purpose of the page, whether be of the group or of an individual broadcasting unit, also affects the definition of editorial guidelines regarding adoption or not of this format. This is a trend in the radio medium in the context of convergence: not only the use of video as crucial narrative strategy, but the adoption of more complex narratives, that meet the demands of different audience profiles, with multiplatform and multitasking features. It is a change in the product that requires radio to review its practices and review the way we think about the medium and its contents. The video that can be seen today as one of the most developed multimedia formats for radio will be accompanied by static info-graphs, interactive and multimedia galleries of images, texts, interactive spaces, games and other productions that compose an effectively cross-media narrative. Right now, however, we would emphasize the importance of taking a step at a time and that when reviewing the routines and setting up hyper-mediatic radio the adoption of video should be considered as a possible format and more importantly there must be a discussion as to its function in this particular medium vehicle. 


\section{NOTES}

1 Paper presented at IX Encontro Nacional de Pesquisadores em Jornalismo (SBPJor), Rio de Janeiro, with the title "Rádio com Imagens: um estudo sobre o uso de vídeos em páginas de emissoras de rádio brasileiras e espanholas".

2 This project is funded by Fundación Carolina, through Programa Movilidad de Profesores e Investigadores Brasil-España and involves, besides the author, the researcher María del Pilar Martínez-Costa, from Universidad de Navarra (Unav), in Spain.

3 The Project "Evolución de los cibermedios españoles en el marco de la convergencia. Multiplataforma e integración periodística", registered under the number CSO2009-1373-C05-03, is coordinated by Professor of the Universidad de Navarra (UNAV), Ramón Salaverria Aliaga and brings together many Spanish researchers who study the process of convergence in different perspectives in printed, radio, television and digital media.

4 As the main objective of the project which includes this paper is to analyze the journalistic uses of technology, we decided, in the analysis, to opt for observing how videos are structured and what role they play on pages of the journalistic radio stations concerned. The institutional journalistic classification is presented in the fourth topic of this article.

5 We emphasize that, according to the coordination of journalism of Radio Guaíba, the website seeks to explore the audio as the main tool and go beyond the antenna content; offers the listener excerpts from interviews that have not been used in the program grid and allow for a more extensive approach to the subject matter.

6 Is noteworthy that this restriction occurred only in videos streamed live from the square. Other productions that integrated the radio and TV content were organized and made available on the hot site for future reference.

\section{| REFERENCES}

AMOEDO, Avelino; MARTÍNEZ-COSTA, María del Pilar; MORENO MORENO, Elsa. Evolución de los cibermedios españoles en el marco de la convergencia. Multiplataforma e integración 
periodística: Herramientas Metodológicas. [mimeo]

BALSEBRE, Armand. El lenguaje radiofónico. $5^{\text {a }}$ ed. Madrid: Cátedra, 2007.

BARBEIRO, Heródoto; LIMA, Paulo. Manual de Telejornalismo: Os segredos da notícia da TV. Rio de Janeiro: Campus, 2002.

BARDIN, Laurence. Análise de conteúdo. Lisboa: Edições 70, 2002.

CASTILLO, María José. Televisión y Lenguaje Audiovisual. Madrid: IORTV, 2004.

CHANAS, Gabrielli. Entrevista concedida a Debora Cristina Lopez e Marcelo Freire. Porto Alegre, 13 de janeiro de 2011.

CURADO, Olga. A Notícia na TV: o dia-a-dia de quem faz telejornalismo. São Paulo: Alegro, 2002.

DEL BIANCO, Nelia. A Internet como fator de mudança no jornalismo.

Revista Brasileira de Ciências da Comunicação. São Paulo, V1, XXVII, Núm 1, Janeiro/Junho de 2004.

FAUS BELAU, Ángel. La radio en el entorno cambiante del siglo XXI. In: MARTINEZ-COSTA, María Del Pilar (coord). Reinventar La Radio. Pamplona: Eunate, 2001.

GARCÍA LASTRA, José María. Entrevista concedida a Debora Cristina Lopez e Marcelo Freire. Madrid, 11 de fevereiro de 2011.

GÓMEZ HERNÁNDEZ, Ignácio. Entrevista concedida a Debora

Cristina Lopez e Marcelo Freire. Madrid, 03 de fevereiro de 2011.

HERSCOVITZ, Heloisa. Análise de conteúdo em jornalismo. In: BENETTI, Marcia; LAGO, Claudia (Orgs). Metodologia de Pesquisa em Jornalismo. Petrópolis, RJ: Vozes, 2007.

JENKINS, Henry. Cultura da Convergência. São Paulo: Aleph, 2006.

LOPEZ, Debora Cristina. Marcos tecnológicos do radiojornalismo no Brasil: uma revisão histórica. In: KLÖCKNER, Luciano; PRATA, Nair (orgs). História da mídia sonora: experiências, memórias e afetos de norte a sul do Brasil. Porto Alegre: EDIPUCRS, 2009.

Radiojornalismo hipermidiático: tendências e perspectivas do jornalismo de rádio all news brasileiro em um contexto de convergência tecnológica. Covilhã: LabCom Books, 2010.

MACHADO, Arlindo. A Televisão Levada a Sério. São Paulo: Senac, 2000. 
MARTÍNEZ-COSTA, María Del Pilar; DíEZ UNZUETA, José Ramón. Lenguaje, Géneros y Programas de Radio: introducción a la narrativa radiofónica. Pamplona: EUNSA, 2005.

MEDITSCH, Eduardo. O Rádio na Era da Informação: Teoria e Técnica do Novo Radiojornalismo. Florianópolis: Ed. UFSC: Insular, 2001.

MIELNICZUK, Luciana. Jornalismo na web: uma contribuição para o estudo do formato da notícia na escrita hipertextual. (Doctorate Thesis) FACOM/UFBA, 2003.

MIRANDA, Ataídes. Entrevista concedida a Debora Cristina Lopez e Marcelo Freire. Porto Alegre, 12 de janeiro de 2011 .

PALACIOS, Marcos. Marginália, 'Zeitgeist' e memória do tempo presente: os comentários de leitores no ciberjornalismo. Brazilian Journalism Research. v. 08, n. 01, 2012.

PATERNOSTRO, Vera Iris. O Texto na TV: Manual de Telejornalismo. $2^{\mathrm{a}}$ ed. Elsevier: Rio de Janeiro, 2006.

RAPHAELLI, Michelle. Entrevista concedida a Debora Cristina Lopez e Marcelo Freire. Porto Alegre, 13 de janeiro de 2011.

RIBEIRO, Ângelo Augusto; MEDITSCH, Eduardo. O chat da internet como ferramenta para o radiojornalismo participativo: uma experiência de interatividade com o uso da convergência na CBNDiário AM de Florianópolis. In: CONGRESSO BRASILEIRO DE

CIÊNCIAS DA COMUNICAÇÃO, 29., 2006, Brasília. Anais...São Paulo: Intercom, 2006. CD-ROM.

RUGE, Peter. Prácticas de periodismo televisivo. Pamplona:

Ediciones Universidad de Navarra, 1983.

SALAVERRÍA, Ramón; NEGREDO, Samuel. Periodismo integrado: convergencia de medios y reorganización de redacciones. Barcelona:

Editorial Sol 90, 2008. 